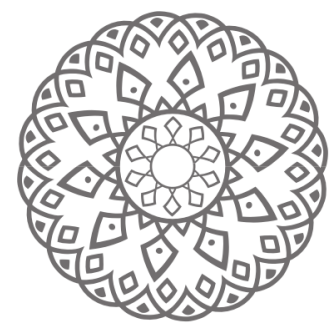

\title{
The Study of The Validity of The Surface Structure of Holy Quran
}

\section{Esmaeil Rezaei, Mohammad Reza Fallah, \& Mohammad Javad Jafari}

\begin{abstract}
Abstrak: Keabsahan struktur permukaan Al-Qur'an adalah salah satu perdebatan Al-Qur'an yang paling penting karena mempengaruhi masalah hukum Islam. Makna struktur permukaan Al-Qur'an adalah bahwa struktur permukaan Al-Qur'an dapat dipahami oleh setiap pembaca dan pendengar, serta teks manusia mana pun, dan apa yang dipahami manusia oleh struktur permukaan Al-Qur'an dengan cara indikasi verbal dan tidak logis. Penelitian ini meneliti validitas struktur permukaan Al-Qur'an, dengan memperluas subjek konseptual penelitian. Mengingat dokumen tematik yang disajikan, pendekatan deskriptif-analitis dengan alat pengumpulan data sumber perpustakaan. Temuan menunjukkan bahwa: alasan paling penting untuk percaya pada validitas struktur permukaan Al-Qur'an adalah bahwa kitab suci ini mencakup rencana kebahagiaan manusia di dunia dan akhirat. Karena itu, jika struktur permukaan Al-Qur'an tidak benar, bagaimana seseorang dapat menggunakan struktur permukaannya untuk menjawab pertanyaanpertanyaan sulit yang membatasi akal manusia. Selain itu, Alquran, meskipun wahyu dari Allah, tetapi karena diturunkan dalam bentuk kata-kata, diatur oleh prinsip dan aturan yang mengatur semua bahasa, di antaranya adalah validitas struktur permukaan untuk mereka yang terbiasa dengan bahasa.
\end{abstract}

Kata kunci: Alquran; struktur permukaan; validitas 
Abstract: The validity of the surface structure of the Holy Qur'an is one of the most important Qur'anic debates, which also affects the issues of Islamic law. The meaning of surface structure of the Qur'an is that the surface structure of the Qur'an is understandable to every reader and listener, as well as any human text, and that which man understands the surface structure of the Qur'an by means of verbal and illogical indications. The current paper examines the validity of the surface structure of the Holy Quran, following expanding the conceptual subject of the research. Given the thematic documents presented, this is a descriptive-analytical paper with library sources data collection tool. The findings indicate that: The most important reason for believing in the validity of the Holy Qur'an surface structure is that this holy scripture includes the plan of human happiness in the world and the Hereafter. Therefore, if the surface structure of the Holy Quran is not justified, how one can use its surface structure to answer difficult questions that limited human reason is incapable of answering. In addition, the Holy Qur'an, although revelation and has been revealed by God, but because it is revealed in the form of words, it is governed by the principles and rules governing all languages, among which are the validity of their surface structure for those familiar with the language.

Keywords: Holy Quran; Surface Structure; Validity 


\section{Introduction}

The surface structure of words and discussion of the validity of surface structure is one of the topics discussed in the Principles of Islamic jurisprudence. This consists of two forms; one is the word by word implication, and the other is the meanings of the words in combination that implies the overall meaning of the words.

This is while the Principles of Islamic jurisprudence scholars have not accepted the classification of the surface structure and believe that it has only one form, that is a signification of the word on the speaker's mindset (Mazhar, without date: 146). However, now, taking into account this issue, it can be stated that the meaning of the validity of surface structure is the authenticity of the reference to the Qur'an. Furthermore, the hadith surface structure is on the extraction of Sharia rules in the sense that if someone acts upon Qur'an or hadith surface structure, his action is in accordance with the Sharia law. Accordingly, the study of the validity of the surface structure of the Holy Qur'an in this article is important taking into account that in our Islamic society, some civil laws and most of its criminal laws, are based on the teachings of the Holy Qur'an.

There is a need to set all life affairs based on the Quran and all community, especially high officials and judges who act upon divine laws and social rights of Islam. Almighty God has revealed for human beings, and this will be possible when the validity of the surface structure of the Holy Quran is verified using the interpretations of the Prophet (PBUH) and the infallible Imams (PBUH) and the commentators of the Qur'an so far. There is a need to outstanding, honest and knowledgeable lawyers who know both religion and science determine and then administer the laws meeting controversies among judge about different interpretation leading to contradictory verdicts. In addition, there may be real and legal persons in their commercial and non-commercial relations, and governments in international affairs use words not conveying the real meanings leading to controversies. Judges and lawyers, in addition to mastering the domestic and international law and jurisprudence, should also have the knowledge of Islamic law, since most of the laws are written by the scholars in law. What we have achieved so far is to say that the intellectual sciences alone have not been able to at all be a substitute for revelation. Therefore, this 
paper aims at proving that the surface structure of Quranic verses can contribute to laws of jurisprudence. And thus the parties to the various contracts are reached.

The current paper aims at answering the following questions: 1 ), what is the evidence of the validity of the surface structure of Holy Quran provided by proponents ?; 2) What is the evidence of the invalidity of the surface structure of Holy Quran provided by opponents?; 3) Which of the abovementioned groups' opinion is logically based on rational and narrative evidence?; What are scientific and legal achievements is the validity of the surface structure of the Holy Quran?

The main hypothesis is that the surface structure of Holy Qur'an, like any other written text, are subject to verbal and linguistic criteria. As the surface structure of any other text can be used by verbal and figurative indications to the purpose of the speaker or writer, it is clear that the verses of the Holy Qur'an are also intended to express the meaning of God, and that which is inferred from the surface structure of the verses suffices to perceive the intention for a person familiar with the rules of Arabic language.

\section{Literature Review}

One of the most important motivations of the researcher in choosing this topic was the lack of comprehensive and clear research in this field. The researcher believes that in spite of conducting research on examining the validity of the surface structure of Holy Quran, so far none of them has independently studied the importance and reasons for considering this rule, as well as the following opinions on the subject of this article, goes on to point out in a different way to the problem of the validity of the surface structure of Holy Quran from the general point of view. However, none of them has specifically addressed the design, confirmation or rejection of the hypotheses of the current paper. Several examples in the literature are presented to illustrate the topic.

The discussion of the validity of the surface structure of Holy Quran are addressed in the following works of authors such as Akhund Khorasani; in Kefayat Alusol; Mazhari in Usol Al-Fiqh; Ayatollah 
Sobhani, in Al-Mojazifi Usol Al-Fiqh; Mohammad Baqer Behbahani, known as Vahid Behbahani in Al-Ijtihad and Al-Akhbar and other related books by Sheikh Morteza Ansari in Faraed Alusol. In addition to them, Mansouri Khaje Langhi, in an article titled "Examining the validity of the surface structure of Holy Quran from the perspective of the clergymen and the scholars", examines the validity of the surface structure of Holy Quran from the perspective of the clergymen and the scholars. The findings of this paper indicate that: Akhbarian theory on the invalidity of the surface structure of the Holy Quran, with all the spectacles expressed by these scholars, is incorrect, and their reasons are lacking in strength and solidity.

In a dissertation entitled "Comparative Study of the validity of the surface structure of Holy Quran and Hermeneutics", Seyyed Mehdi Sarvari addresses literary and semantic meanings in principle and the thoughts and then examines the nature of the surface structure. In the following, we examined the validity of surface structure and finally, the comparative study of hermeneutics and the validity of surface structure and the semantic relation from the point of view of hermeneutics and principles, the control of prejudices and rules of hermeneutics, the possibility of rebuilding religious rules and the possibility of reconstructing the horizons of the issuance and discovery of surface structure, complying with the veracity of surface structure and hermeneutics.

Sedigheh Mir Shamsi (2014), in an article entitled "The validity of the surface structure of Quranic verses", argues that the discussion of the validity of the surface structure of the verses is, in fact, the discussion of the principle of the validity of the verses because if the surface structure of the verses are not valid, given that the texts are very small, there will not be the verses as the main reason for the precepts, nothing remains to be cited in the inference of the religious law. The author believes that the validity of the surface structure of Quran verses like the surface structure of the Sunnah and other texts is due to a definite valid reason. He considers the most important reason for the validity of surface structure is the rational souls conducts.

Sarim Sayyafullah (2013) also discusses the controversy of the verses and principles concerning the validity of the surface structure 
of the Qur'an in an article titled "Reviewing the controversy among the clergymen and the scholars in the validity of surface structure of the Holy Quran”. Further, in the arguments of these two groups, he believes that by clarifying the relationship between the traditions and the Quran and gaining the length and breadth of this relationship, the status of the Qur'an will be obtained in the Islamic legal system.

\section{Innovation in Research Background}

Literature review shows that none of these backgrounds has examined the main issue, namely, the validity of the surface structure of Holy Quran, but the general weakness of all researches are directional and pays attention to the consequences at the level of the surface structure by the clergymen and the scholars. Therefore, none of the sources studied directly and simultaneously studied and explained the subject of this research and has only referred to the general and indirect references to this issue. But the research attempts to study this issue scientifically and academically, and by identifying the reasons for the validity of the surface structure of Holy Quran, it will identify the benefits and positive implications of it in community.

\section{Reviewing the validity of the surface structure of Holy Quran}

The validity of the surface structure of the Holy Quran is one of the most important rules. So, here we look at this important rule.

\section{Explaining several key terms Definition of the basic term with the Qur'anic example}

The word Ghaedeh in Arabic means the root; the Holy Qur'an uses the word to refer to the word "rule"; those who had gone before them also plotted. Then, Allah came upon their building from the foundations, and the roof fell on them from above them. And the punishment overtook them from where they did not know. (Alnahl/ 26)

\section{The word Ghaedeh in the Holy Quran}

Allah says in: Baqara / 127 "And when Abraham and Ishmael raised 
the foundations of the House (supplicating): 'O our Lord, accept this from us, You are the Hearer, the Knower.",

\section{The terminological meaning of the term Ghaedeh}

The semantic meaning of the Ghaedeh is closely related to its lexical meaning, Tahanawee writes in the description of the terminological meaning of the term Ghaedeh: "... The general rule is that when identifying the details of it, it conforms to all its details." (Tahanawee, $1158 \mathrm{AH}:$ 1176). If the meaning of the term is seen in comparison to the lexical definition, the relationship will be clear, because each general subject is the same as the basic one and all its details.

\section{Linguistic and Idiomatic meaning of the surface structure:}

We now explain the meaning of surface structure, and then we discuss validity in order to make the pillars and concepts clear because these two words can complement each other in this regard.

\section{The word surface structure}

The surface structure is contrary to the deep structure; the former is about the surface meaning, while the latter concern the hidden meaning. (ibn al-iwah, 1995: 520).

\section{Idiomatic meaning of the surface structure:}

The origin of the surface structure of the surface structure is the signification of an idea derived from the state or meaning of customary admission, so that if a word uttered is issued by a theologian is such that it is established that the speaker is serious and does not intend to have a joke, and is in the form of expressions and deeds, meaning is connected and the signs are not based on the will of the opposition to the subject of the affair, the authentic signification or validity in the word is concluded. The surface structure, whether or not it is an affirmation, is of two kinds: a) personal or present surface structure. The surface structure that is created in the mind of a certain person is influenced by personal factors, in each individual, depending on the subjectivities of that person, and is, in fact, subject to personal 
interests; however, surface structure in a particular or thematic sense. The surface structure is due to lexical interests and the general forms and modes in every language and customary, and this is the surface structure that is the subject of authority for most scholars rather than personal surface structure (Sadr, 1415 AH: 3/188). The purpose of the surface structure here is the literal surface structure in the sense that the listener understands the speaker as one of the common people, and his words refer to it as the speaker's intended purpose; whether the implication of the word on that meaning is conditional or not, because the mind of the listener moves in that sense. As they say in the implications of the word on that meaning (Mümin Al-Qomi, 1419 AH: 45). In the term, the surface structure is used verses the deep structure. The difference between the two is that the implication of the verse on the meaning of the purpose is explicit in the former, but is implicit in the latter in that it means that the speaker's intention is different from what perceived in the surface structure. (Hakim, 1418 $\mathrm{AH}:$ 164).

\section{Surface structure}

Surface structure refers to something that appears on the surface. In the culture of the Qur'an, everything is visible and obvious, surface structure and secret things are said to be inward, such as: worldly and the afterlife (Isfahani, $1404 \mathrm{AH}: 317)$.

\section{Validity}

\section{The meaning of validity}

Validity is the extent to which a concept, conclusion or measurement is well-founded and likely corresponds accurately to the real world based on probability. The word "valid" is derived from the Latin validus, meaning strong. (Sobhani 2008: 21).

\section{First Chapter - Review the Originality of the Surface structure in the Holy Quran}

In this chapter, the principle of the surface structure of the Qur'an is considered. In order to understand the rule of surface structure, it is necessary to consider the rule in the Holy Qur'an 
in the field of jurisprudence and the laws of the subject. With the advent of Ekhbariun in the 19th century AH, the validity of surface structure has been questioned in many respects, and some scholars denied the validity of surface structure of the Quran. They explicitly accepted the distortion of the Qur'an and sought to prove it. The relative domination of their thinking over the Shi'a sect did not last for more than a century, but some of the results of their views persisted. Usoli scholars from the very beginning began to confront and criticize their opinions so that now all scholars of jurisprudence and Usol in theological sciences emphasize the validity of the surface structure. But in the jurisprudential rules, we have other rules that are closely related to the rule of the validity of surface structure. To better understand the subject, we will explain one of these. These rules include the rule of Yad, the rule of Farash, the rule of Ofo Beloghod or Oghod Tabeta Lelghosod, and here the rule of Yad is studied.

In jurisprudence, there are various rules that are devoid of specific purpose; some of them are only legal or principled principles, and some, are in adopted in jurisprudence as well as law. The rule of Yad is as the jurisprudence and law rules. The significance of this rule and its widespread use has led to the use of this rule by jurisprudents and jurists in their remarks and writings, and, of course, the ordinary people also refer to it.

\section{The rule of Yad}

The rule of Yad is one of the most important rules of jurisprudence, Islamic law and principles, especially in Imamia jurisprudence, as well as Islamic law. In many ways, the rule of Yad can be considered as one of those aspects of acquisition and ownership, including such things as the revival of the mind.

\section{Yad (hand)}

Yad in Arabic means from fingertip to wrists, man uses most of the things by hand, and it is used to idiomatically refer to the acquisition of properties and claimed ownerships, and in the term, as mentioned (for example, to catch fish by hand which leads to the ownership). It 
should be noted, however, that in this regard, the custom of society is important.

The word Yad is sometimes used in its virtual sense, i.e., dominance, and the dominance here means dominance in action, such as that we can retrieve some of the objects, but until we have completely captured it we have no rights to the property. Of course, it should be noted that dominance is proven when it is in action. In order to understand whether a person owns a financial property, he or she is usually paid attention to the custom of society. This is because man's dominance and authority on things are different.

It is as if someone on the spot around the city had built a barricade and settled there, nobody would have been thrown at them for thirty years, but later, when the land was placed inside the boundaries of the city, it should be looked at the custom. Whether this person is usurping or not, since according to the various verses of the Qur'an, anyone who grows a land is the owner and domination unless it is proved to be contrary to it. Or someone has a dress that does not prove to be the opposite, we can not acknowledge that the clothes worn by them are not, and we can accept the surface structure and authority of the surface structure principle that the clothes belong to them, or someone is riding on a car and it on the way, it is guided by the surface structure that we must confirm that the car belongs to him. In this regard, we conclude that the owner is one of the powers and the hegemony and the financial possession which he possesses can seize or change whatever he wants to do in that property. If he/she wants to own it and if he/she claims to be claiming that this property does not belong to this person, he/she should prove it to be a proof of the reasons and documents he/ she claims.

It should he/she that the rule of Yad is both approved and signed by the Muslims and accepted by all other religions of the various countries, and if anyone controls an asset, we will recognize that the property belongs to them.

\section{The rule of Yad in the Holy Quran}

Considering that the rule of Yad is based on the rules of Islamic jurisprudence and most jurisprudents have discussed it, we also 
discuss this rule in different ways, as we see in the Holy Qur'an for that, because the rule of Yad itself is the reason for the rule of the validity of surface structure. The Imam said: "If this did not happen, Muslims would not have a market ". First, it is the cause of ownership. It is explained in this aspect as the topic of discussion of the rule, and now we present the verses of the Qur'an that have come to mind in the rule. The term Yad in the Holy Quran has come to various shapes and concepts, as well as the word in terms of number in singular, blessed, and aggregate, and has various true and evident meanings which according to the meaning of the verse can be understood as the intended meaning. Here, are some of the verses of the Holy Qur'an, in which the term Yad is used and has different meanings.

\section{Yad means the achievement of a person}

"If affliction befalls you, it is what your own hands have earned, but He pardons a lot." (Shora / 30). Here Yad means that human beings reward or punish according to the work they have done and, as it says: "I have to do what I want to do, but do not kill yourself with your own hands"; "As well as and do not cast into destruction with your own hands".

"Spend in the way of Allah and do not cast into destruction with your own hands. Be good-doers; Allah loves the good-doers. "( Baqara / 195).

"Corruption has appeared on land and sea with what the hands of the people earned. Therefore, they taste some of what they did so that they return" (Al-rom / 41).

\section{Yad means hands}

Here, the abstraction is from the very same meaning that is the true meaning of the hand, which means one of the parts of the human body, which every activity can be done with the help of that is mentioned in the Holy Qur'an in many cases.

"The Jews say: 'The Hand of Allah is chained. 'Their own hands are chained! And they are cursed for what they said! Rather, His Hands are both outstretched; He spends as He will. That which Allah has sent down to you will surely increase the tyranny and disbelief of many 
of them. We have stirred among them enmity and hatred up until the Day of Resurrection. Whenever they kindle the fire of war, Allah extinguishes it. They spread corruption in the land, and Allah does not love those who corrupt. " (Maedeh / 64)

"Woe to those who write the Book with their own hands and then say: 'This is from Allah, ' in order to gain a small price for it. So woe to them for what their hands have written, and woe to them for their earnings. "( Baqara / 79).

"Upon that Day the harm doer shall bite his hands, and say: 'Would that I had taken a Path with the Messenger! "(Forghan/ 27).

If you stretch your hand to kill me, I shall not stretch mine to kill you; for I fear Allah, the Lord of the Worlds. “ (Maedeh / 28)

\section{Yad means the power of insight}

(Muhammad), recall Our servants Abraham, Isaac, and Jacob, all of whom possessed virtuous hands and clear visions. "( $\mathrm{Sad} / 54)$.

Those who swear allegiance to you swear allegiance to Allah. The Hand of Allah is above their hands. He who breaks his oath breaks it against his self, but for he that keeps his covenant made with Allah, Allah shall give him a mighty wage. "(Fath/ 54).

\section{The principle of surface structure status}

The principle of surface structure is used where the word appears in a certain sense, but it is not so explicit that the opposite can not be considered, but it is also possible in the opposite of surface structure in the text of that word or sentence. Explaining the validity of the surface structure of the Quran in most Jurisprudence books are expressed as a discussion issue, and principles have been discussed in relation to the implications of Qur'anic surface structure, including Sheikh Ansari in Fareed al-Usol, Allameh Mohammad Reza Mozaffar in the jurisprudence, Akhund Khorasani in Kefayat Al Usol as well as "Sheikh Mofid "," Seyyed Morteza "," Vahid Behbahani and Sheikh Tusi, and some other commentators and scholars, as well as Akhbaris also have discussed this issue in the Quran (M0zafar, 2005: 46).”,14 


\section{The Jurisprudence}

The Jurisprudence has stated that the Shari'a's arguments are classified into three groups, which are briefly described here.

Solid evidence, such as those with clear proof and are valid in the case of non-compliance;

Probable evidence, such as the surface structure of verses that are inadequate in the proof and valid in the case of non-compliance and validation of the intellect.

Insufficient evidence that there is no sufficient evidence that is the ground for the implementation of the Esteshab, Ehtiyat, Takheer and Beraat (Helli, 2001: 5).

On the Jurisprudence four arguments (Quran, tradition, consensus, and reason), it has been stated that the first principle of subjection the surface structure is unreliable and insufficient unless there are, unity, consensus, and reason (Helli, 2001: 62).

\section{Akhbari's and the reasons for the invalidity of its surface structure}

Prior to the Akhbaries, such an issue was not addressed either in the Shi'a principle or in the Sunni principle. The Akhbaries have not raised the issue of the validity of the surface structure of the Qur'an for the first time, but it was formerly emphasized as the unique ways of discovering the rules of sharia in narratives, necessarily denying the extraction of ordinances from the Quran. Likewise, they have also denied reason as a source of ordinances (Cerami, 2013: 12-60). Akhbaries says that the surface structure of the Qur'an can not be performed unless the Qur'an verse is interpreted through news and narrations. Nevertheless, the Usolies believes that the Qur'an surface structure is valid even in the absence of news. It should be noted that for two centuries, there was a profound contradiction between the Usolies and Akhbaries scholars, and the Usolies predominated on the Usolies, so that Mr Mohammad Baqir Vahid Behbahani (1208 AH) dismantled them and, since his time, the Mujtahids overcome the Akhbaries, and today Akhbaries is very much a minority. It is worth noting that the surface structure is of different kinds, and the purpose of the validity of surface structure in the interpretation is the surface structure discovers the Almighty God intention, albeit a subjective 
discovery. To achieve this, we need to mention the Qur'anic verses in terms of the words and surface structure

\section{Implications of Quranic verses}

The most important way of obtaining the holy verses intentions from the texts of the book and the tradition is the surface structure of words. Since the surface structure is the words used by the speaker to convey a meaning, it is rationally and reasonably necessary for his credibility to be definitive in order to be able to be positive and capable of being evidence. This reason has been expressed and proved mainly from the rational system and the Jurisprudence discipline by scholars in the context of the validity of surface structure. With such a reason, the surface structure of words is a valid and reliable way of obtaining the terms of the book and tradition. From this credibility, the evidence of surface structure is proven on the perception of the concept conveyed by the speaker by the listener or reader. (Cerami, 2013: 12-60)

\section{The Qur'anic text is classified into two deep structure and surface structure, like any other text.}

The obvious word in the single meaning without the possibility of falsity and ambiguity is called seed structure. And in Quran deep structure is where the purpose of the text is explicit without a need to be interpreted and explained, and there is no possibility of meaning and notion other than the meaning that is perceived by the listener. In another words "deep structure", without the intervention of another, clearly implies meaning, and that meaning is the main purpose of the revelation of the verse or the decree of the judgment (Zahili, 46: 2002).

In other words, "the deep structure is clearer than the surface in perception, and this clarity is not more than the word itself, but it is from the specter that the theologian brings with words, so "surface structure ", is regardless of its contours. This is the same as the word main meaning, such as "Allah has permitted trading and forbidden usury” (Baqara / 275). The surface structure of this verse signifies the legitimacy of the sale of goods, but the main purpose of the 
verse is not this, but the verse indicates that the purpose is to express the forbidden usury since this verse also reads that "Selling is like usury" (Baqara / 275). Almighty Allah has permitted trading and forbidden usury. In this verse, we find that the verse indicates the difference between trade and usury because implies this meaning, and the verse refutes the claim of usury-based on the similarity to the trade (Sarakhsi, 1414AH: 164).

\section{The difference between the deep structure and the surface structure}

The difference between the surface structure and the deep surface is that the deep surface meaning in the text is the ultimate purpose, but the surface structure meaning is not, first and foremost, meritorious, but rather subjunctive and lateral, in the direction of the background and it is intended to induce the original meaning. In order to figure out the main purpose of the verse, it is necessary to pay attention to the following points (Fathi El Dorin, $1434 \mathrm{AH}: 51$ ).

\section{Classify the words of the Holy Quran Deep structure}

The deep structure of Holy Quran clear in its content and contrary to "surface structure" cannot be interpreted, and in the term, is clear and obvious that there is no possibility of contradiction in revelation. In other words, the meaning in the word is not probable.

\section{Surface structure}

"Surface structure" has one of two or more meanings that one may dominate the other meanings. Therefore, the Qur'anic deep structure is a verse which, in the sense of purpose, is an explicit; as if it was between two similar things, which is good and which is bad, i.e., "Allah has permitted trading and forbidden usury" (Baqara / 275) and " $\mathrm{He}$ is the First and the Last, the Clear and the Hidden. He has knowledge of all things." (Hadid / 3).

\section{Deep structure in the Qur'an and Sunnab}

Linguists have there are few deep structures in the text of the Qur'an and the Sunnah is, but Imam al-Harmānī says that the purpose of the 
deep structure is an independent definitive meaning that there are no paths of probability and abstraction in it, and this, albeit with a lexical reference, however with plenty of testimonies and contradictories. For example, Al-Suyuti provides evidence for deep structure, i.e. the verse 196 of Baqara "Let him fast three days during the pilgrimage and seven when he has returned, that is, ten days in all." (Baqara / 196) Except for the completion of ten days of fasting, this verse does not imply other meaning.

\section{Some scholars' opinion about the Deep Structure and the Surface Structure \\ Ayatollab Sobhani}

Deep structure is explicit in expressing what is meant by the speaker, and there is merely a single meaning (Sobhani, $1428 \mathrm{AH}: 84$ ). In the cases of deep structure, the meaning is quite clear in terms of the state of meaning and the manner of its application, and what is meant by the speaker and contrary to it, does not come to mind. Such as the deep structure in the following verse: "You are the best nation ever to be brought forth for people. You order honor and forbid dishonor, and you believe in Allah.” The verse is seemingly has a deep structure, but it is necessary to surface structure: It is also said: "the surface structure implies the obligation" (Meqdad, 1422, AH: 373). "surface structure is when the word does not explicitly refer to its meaning (Sobhani, 1412, AH: 84).

\section{Mohaghigh Ardebil}

"So it should be explicit about what is required " (Ardebili, 411: 1381)

\section{Fazil Meqdad}

"This verse is explicit in the matter, and it was narrated by those who said that it is sufficient". Although the verse may have the surface structure of necessity, it can be cited for the explicit reference to the verse "fasting is decreed for you" (Baqara / 183), which is explicitly written, but it is not explicitly required (Maqdad, 1422: 373). 
The other examples of deep structure verses are: "Then, let the pilgrims accomplish their acts of cleansing, and let them fulfil their vows, and circumambulate the Ancient House." (Haj / 29), and "Do not eat from that which the Name of Allah has not been mentioned, ... " (Anam/121). The first verse is explicit in the necessity of Tawaf and Jihad, and the second verse explicitly is in the abandoned what is not named by Allah (Makdad, vol 2: 225).

It is necessary to explain that if a verse is presented clearly in the Holy Qur'an, it is possible to understand the verse and understand that it is for the duty, so everyone has the duty to accept it and to act upon, because the purpose of the verse, which is the view of the Almighty God has come to the satisfaction of the Almighty God. "those who, if We established them in the land, will establish the prayers and pay the obligatory charity, order with honor and forbid dishonor, and to Allah is the end of all affairs." (Haj/ 41 ). The deep structure is easily recognized by everyone as everyone should pray, pay zakat, and advice to good and forbid bad. However, there may be other goals to look at.

It should be noted that sometimes the term may not be explicit in the implications of its meaning, and the speaker has another purpose, such as "establish the prayer " (Younis / 87). The other verse of the Qur'an, like: "Establish your prayers, pay the obligatory charity, and bow with those who bow", and "Recite what has been sent down to you of the Book, and establish the prayer. Prayer forbids indecency and dishonor. The remembrance of Allah is greater, and Allah knows what you do." (Al-ankabut/ 45). It seems that in view of the surface structure of various Quranic verses, we can not figure out that prayer is obligatory and we must perform prayers, and there is no clear reference to compulsory prayer in the Holy Qur'an.

\section{Study of Surface Structure}

Surface structure verses deep structure is relative and archetypal, and every expression of the verses contains a surface structure that is the deep structure to the next surface structure (Barghi, 274: 300).

Therefore, in some narrations that the Quran has surface 
structures, each of which with another surface structure (Bihar alAnwar, 2014: 91). On the surface, some of the verses of the Qur'an are the opposite of my words. Such verses can be interpreted, and other meanings can be provided by the interpretation of the verse, which, of course, all these meanings are in line with each other. Of course, the reception of the verse and the interpretation of it are not in the power of any individual, but in the expert power of interpretation (Mozafar, 2013: 156).

\section{Second Chapter: The Validity of the Surface Structure of the Quran}

Evidence of the validity of the surface structure of Qur'an versus the deep structure of Qur'an

The Qur'an is a holy book, and, as mentioned, it has a surface structure against the deep structure, and the interpretation of its surface structure is based on the supposition of its supposedly correct commentators (Hakim, 2004: 96).

Most Akhbares do not believe in the validity of its surface structures and believe that the Quran cannot be understood by ordinary people and is beyond their comprehension and merely is perceived by commentators, so the surface structure of the Qur'an is not valid. However, some scholars, such as Sadr find surface structure valid (Sadr, 1423: 180). To prove the validity of the surface structure of the Qur'an, we can refer to the verses of the Qur'an, which expresses the validity of the surface structure of the Quran.

\section{Verses Indicating its Reason and its Necessity for the General Public}

"Will they not then contemplate on the Koran? Or are there locks upon their hearts! " (Mohammad/ 24);

"Will, they not contemplate upon the Koran? If it had been from other than Allah, they would surely have found in it many contradictions." (Nissa/ 82);

"And when the idolaters see their associates they will say: 'Our Lord, these are our associates on whom we called other than You.' But they will throw back at them saying: 'Surely, you are truly liars." (Nahl/ 86). 
Verses indicating the simplicity to perceive meanings by the general public

"We have now made it easy on your tongue so that they remember." (Dokhan/ 58);

"We have made the Quran easy to understand, but is there anyone who would pay attention? " (Ghamar/ 17).

The verses that indicate the Qur'an challenge

In some verses of the Holy Qur'an, challenges those claim that it is not revealed on the Prophet Muhammad, saying that if there is doubt in the verses of the Quran ....

"If you are in doubt of what We have sent down to Our worshiper (Prophet Muhammad), produce a chapter comparable to it. Call upon your helpers, other than Allah, to assist you, if you are true." (Baghara/ 23)

"Have they feet to walk with? Have they hands to punish with? Have they eyes to see with? Have they ears to hear with? Say: 'Call on your partners and then try to scheme against me. Give me no respite." (Aaraf/ 195).

Therefore, according to the above verses and many other verses of the Holy Quran that are not included in this article, we conclude that the word is used in its true meaning and appears therein, that is, when the use of the word in a certain sense (the real or virtual) and the chance to go against it, we should prove the validity of the surface structure (Feiz, 2016: 88).

\section{Some Comments from the Scholars on the Validity of the Surface Structure of the Quran}

Regarding the surface structure meaning of the Qur'an is called the validity of the surface structure of the Qur'an, and it is based on the fact that we can consider the surface structure of Qur'an in a number of cases and make it a criterion of action, and accept them in our speeches and practices, because the surface structure of the Qur'an can be perceived by the public, because otherwise, the affairs of the Muslims who have adjusted their rules to the Qur'an will end up with troubles. 


\section{Alireza Feiz}

Alireza Feiz believes that all the figurative speeches that are forms used in the surface are being used in "Almighty Revelation." $\mathrm{He}$ believes that: in fact, we have a "revelation", according to which we understand the meaning of the Qur'anic verses so that those who are familiar with the Arabic language and the interpretation and explanation of the Quranic words can easily understand the surface structure of the verses of the Word of Allah and the purpose of the Almighty God.

\section{Allame Tabatabai}

The surface structure of the Qur'an is meant to be used from the corresponding signifier of the verse; in other words, the surface structure of the Qur'an is something that everyone understands with the eloquent Arabic word, it first understands it from the verse. According to him, the surface structure and the inner side of the two are relative, and both are expressed by the word, except that these two meanings are contemplated along the length, not in the same way; that is, not the will of the surface structure of the word is the rejection of the will of the inward instead, the inward will, the intruder of the will appears, for example, from this verse: "Worship Allah and do not associate anything with Him. Be kind to parents and near kin, to the orphans and the needy, to your neighbor who is your kindred, and to the neighbor at your far side, and the companion at your side, and the destitute traveller, and to that which your right hands own. Allah does not love him who is proud and struts". (Nissa/ 36)

From the beginning of the verse, we find that we serve God and do not worship idols, but Ayatullah Tabatabai believes that, in addition to not worshipping idols, but with a clearer view, man should not worship other than God, Human beings should not even follow their hearts, and God should not be neglected and despise others (Tabataba'i, 1971: 72).

Verses from the Holy Quran indicating the contemplation on the meaning of the Qur'an, "Will they not then contemplate on the Koran? Or are there locks upon their hearts! " (Mohammad/ 24); "We have made it an Arabic Koran so that you understand. " 
(Zokhrof/ 3);" It is He who has sent down to you the Book. Some of its verses are precise in meaning they are the foundation of the Book and others obscure. Those whose hearts are swerving with disbelief, follow the obscure desiring sedition and desiring its interpretation, but no one knows its interpretation except Allah. Those who are well-grounded in knowledge say: 'We believe in it, it is all from our Lord. And none remember except those who are possessed of minds." (Al-Imran/ 7)

\section{Ismaili Sect Perception from the Surface Structure and the Holy Qur'an}

The Ismaili sect perception of the validity of surface structure is gone beyond the limits of moderation, is a state of extremes; it means that they have only accepted the inwardness, set aside the surface structure of the field of action, and put it out of credit, and say: " Surface structure is a skin, and the interior is like the brain "and to justify their beliefs, they refer to the last part of verse 13 of Hadid's Surah: "On that Day the hypocrites, both men and women, will say to the believers: 'Wait for us so that we can take from your light. ' But they will be answered: 'Go back and seek a light!' And a wall with a door shall be between them. Inside it, there is mercy, and outside will be the punishment. " (Hadid/ 13).

\section{Vahid Behbahani}

Also, Vahid Behbahani, in response to the critique of the Akhbaris, considered the "consensus" inspired by the Sunni methods, that "consensus" between us and the Sunni scholars had verbal contributions and, rather than a consensus that we believed in its authority. We have the fundamental difference with the consensus that Sunni believes in. Sunnis believe the consensus is in themselves as the proof, but the jurists of the Imamiya (PBUH) believe that consensus is a way to study the infallible promise (peace be upon him). Educational conditions are considered innocently by consensus in the science of Jurisprudence. 


\section{Summary of some of the most Important Behbahani Reviews to Akhbaris Views}

The scholar, Behbahani in response to the Akhbaris who believed that "Qur'anic surface structure" validity as interpreted by self-views, said that all infallible imams have resorted to surface structure of the Qur'an. It is an act of the Qur'an and is considered as a "Qur'anic Thinking", and this is very different from the interpretation of the Qur'an by self-views because the surface structure of words is following the custom of the Sharia law.

This Akhbari scholar, in rejecting the opposition of the Akhbaris with the "power of reason", in order to deduce the religious order, wrote a treatise on good and bad reason, in which it proved the validity of the intellect in the intellectual capacities and made clear that the narrations as the sources to infer religious law, in fact, refers to the subordinate sentences of the intellect in ways that are analogous and inhuman, and, otherwise, in the definitive decrees of reason, which have no right in the virtue of its authority, that is the ruling of reason and the like, which abundant in the traditions of the infallible Imams.

The Akhbaris believed that "all the hadiths" of the infallible in the famous and authentic books such as "Four books" are definite and we do not need the knowledge of Rijal to examine their documents. Behbahani also rejected this view, and in the book "Al-Rasayl alUsoliya", the book "Ijtihad and Akhbar" proved the need for the science of Rijal. In addition, he, with initiatives in the science of Jurisprudence, opened a new chapter in this science and led to its growth (Makarem Shirazi, 123: 2006)

\section{Conclusion}

The current paper concludes that: First, the surface structure of the Holy Qur'an is valid, because if it is other than that, not only will the Muslims be disconnected from their scripture, but the trust of the Muslim community will be discarded because what is important is the perception of the content by the audience, and only in that case, that the word will be valid for the audience. Second, the validity of the surface structure of the Holy Quran, such as the surface structure of the Sunnah and other implied verdicts, will require, for a definite authority, to be 
arranged in an orderly fashion and logical order to be able to determine the definitive optimality, so that the examination of the rule of law becomes important. And this issue can be very effective in interpreting laws based on the Qur'an. Third, the readers will pay more attention to research in the Quran and its verses. The author suggests that scholars, commentators and university professors regarding Qur'anic studies to be more active because all the affairs of the world and the Hereafter have conveyed to us in the Holy Qur'an, which believes that the Qur'an's surface structure can be verified through the Quranic teachings that guarantee the prosperity and happiness of Muslims in the world and the Hereafter.

\section{References}

Ansari Dezfuli, Morteza, 1427, Faryad Alusoll, Qom: Assembly of the Alfagh alIslami.

Barghi, Ahmad ibn Muhammad ibn Khalid, 1992, Al-Muhasen, Qom: Dar al-Sab al-Islamiyah.

Cerami, Seyfollah, 2013. Qur'an's Position in Deducing Judgments, Second Edition, Qom: Bostan Book (Publishing Center of Islamic Propaganda Department of Qom Seminary.

Hakim, Mohammad Taqi, 1418, Al-usol al-'Ame’a Lalfāq al-Muqarran, Qum: World Assembly of the Ahlal-Beit (PBUH).

Helli, Hassan ibn Yusuf, 2001. Tahzib Al-usol, London: Alamam Ali (AS) Institute.

Hosseini Zabidi Sisati, Seyyed Morteza, 1212 AH, Taj Alarus, Beirut: Dar al-Fakr Ibn Manzur, Muhammad ibn Makram, 1414 AH, Lassan al-Arab, Beirut: Darsadar.

Esfahani, Ragheb, 1404 AD, Almofradat Fi Gharaib al-Quran, Egypt: Office of the Publishing House.

Tahanoee, Mohammad Ali, 1158, Kashaf Estelahat Alfonon, Beirut: Lebanon, Nashroun.

Khoei, Abolqasem, $1430 \mathrm{AH}$, Al-Bayan fi Al-Tafsir al-Quran, Qom: Islamic Revival Institute of Imam Khoei works.

Khorasani, Mohammad Kazem, 1991. Kafayyat al-usoll, Qom: Ahlal-Beit Center.

Majlesi, Mohammad Bagher, Bahar Alanwar, 2014, Beirut: Darahiyat Altar alArabi.

Mazhar, Mohammad Reza, Principles of Jurisprudence, Tehran,: Ismaili Publishing. Moghadas Ardebili, Ahmadben, 1982, Zabdat al-bayan, Tehran: Al-Martazaviyah Library Makarem Shirazi, Nasser, 2006. Encyclopedia of the Contemporary Jurisprudence, Qom: Alamam Aliban Abitarib (AS) school. 
Moghadad, Fazil, 1422 AH, Kanzal Arafran, Qom: Navid Islamic Library.

Mozaffar, Mohammad Reza, 2007, Al-Fighh, Qom: Ismailis.

Momin Qomi, Mohammad, 1938. Tasdid Al-usol, Qom: Islamic Publishing House.

Sadr, Mohammad Baqir, 1405 AH, Lessons in Usol, Beirut: Daralmontaze.

Sobhani Tabrizi, Ja'far, 1428 H, Al-Hadith Va Ahkam, Qom: Imam Sadiq Institute.

Sobhani Tabrizi, Jafar, Al-Muhuselifi Alam Al-usol, Qom: Imam Sadiq Institute.

Tabatabai Hakim, Mohammad Saeed, 1414 AH. Al-Muhkam Fi Usol Al-Fiqah, Qom: Al-Manar.

Tabatabai, Mohammad Hussein, 1971, Al-Mizan fi Tafsir al-Quran, Beirut: Institute for the Study of the Press. 